\title{
Found in Translation: The Reception of Andrei Ivanov's Prose in Estonia ${ }^{1}$
}

\author{
ANNELI KÕVAMEES
}

\begin{abstract}
Andrei Ivanov (b. 1971) is the most well known Estonian Russianlanguage writer who has won many literary awards in Estonia and Russia. His prose and position in the literary field of Estonia has initiated the discussion about the exact definition of Estonian literature and the status of the Estonian Russian-language literature. Due to Ivanov's prose, the world of Estonian Russians has become more visible for the Estonian audience. He also gives a piercing look into the modern society and offers a different perspective on the world; these are some of the reasons of his popularity. The article focuses on the analysis of the reception of Ivanov's prose published in Estonian. The vast majority of Ivanov's prose has been translated into Estonian: Путешествие Ханумана на Һолланд, Харбинские мотыльки, Бизар, Исповедьлунатика, Горсть праха, Печатный шар Расмуса Хансена, Мой датскийдядюшка аnd Зола. The author has entered the Estonian cultural field through translations, it may be said that he has been found in translations. Ivanov's books are bestsellers and widely discussed in newspapers, blogs and in the literary magazines. The position of Estonian Russian literature has shifted from the periphery into the spotlight and the works by Ivanov have played a decisive role in that process. The article focuses on the analysis of the reception of Ivanov's prose published in Estonian. The articles published in the Estonian language and concentrating on his prose (both in newspapers and in the literary magazines) are under observation. What topics have been discussed? Which aspects of Ivanov's prose have attracted the attention of the critics?
\end{abstract}

Keywords: Estonian Russian literature; Andrei Ivanov; reception; translations

\section{Introduction}

Andrei Ivanov (b. 1971) is the most well known Estonian Russian-language author whose prose has won many awards both in Estonia and Russia. For example, the novel Путешествие Ханумана на Аолланд ('Hanuman's Journey to Lolland') was nominated for the Russian Booker Prize in 2010 and won the

1 This study was supported by the Estonian Ministry of Education and Research (IUT 18-4), and by the European Union through the European Regional Development Fund (Centre of Excellence in Estonian Studies). 
KÕVAMEES

Estonian Cultural Endowment literary prize for the Russian-language author in 2009; Харбинские мотыльки ('Harbin Moths') won the same prize in 2013 and in 2014 the novel won one of the most important literary priczs in Russia NOS. In 2016 Исповед лунатика ('Confession of a Lunatic') won the Estonian Cultural Endowment literary prize for the Russian-language author. The cultural award for outstanding creative activities in 2015 was given to Ivanov by the Republic of Estonia as well. ${ }^{2}$

His prose has been published in book form and in the literary magazines in Russia, the USA and Estonia. In Estonian the following novels have been published: Путешествие Ханумана на Аолманд (2009) (Hanumani teekond Lollandile, 2012), Харбинские мотыльки (2013) (Harbini ööliblikad, 2013), Бизар (Bizarre) (2014) (Bizarre, 2014), Исповедь мунатика (2014) (Kuиtõbise pihtimus, 2015) and Гopcmь npaxa (A Handful of Dust) (2014) (Peotäis põrmu, 2011). ${ }^{3}$ His stories Печатный шар Расмуса Хансена (Rasmus Hansen's Writing Ball) (Rasmus Hanseni kirjutuskera, 2015), ${ }^{4}$ Мой датский дядюшка (My Danish Uncle) (2007) and 3oлa (Ashes) (2008) (Minu Taani onuke. Tuhk, 2010) have been published in Estonian as separate books; Связка (A Bunch) (2011) (Kimp, 2013) and Телеграммы из Альтоны (Telegrams from Altona) (Telegrammid Altonast, 2014) have been published in the literary magazine Vikerkaar. As may be concluded from the list, Ivanov is a very popular author whose books are quickly translated into Estonian and there are cases when his books are first published as translations in Estonian. Therefore, it may be said that Ivanov has firmly entered the Estonian cultural field through translations.

The position of the Estonian Russian-language literature has shifted from the periphery into the spotlight and the works by Ivanov have played an important role in that process. His novel Peotäis põrmu, for example, started a discussion about the exact definition of Estonian literature and the position of the Estonian Russian-language literature (the issue is more thoroughly discussed in Kõvamees 2014 and Kõvamees 2015). Ivanov has been called a perfect storm (Trunin 2016b), meaning he frees himself from culture and breaks traditions, but the metaphor may also be interpreted the other way. Namely, every early spring when the annual literary prizes of the Estonian Cultural Endowment are nominated, the works of Ivanov are widely discussed and the limitations of the prizes are argued about. Indeed, Ivanov may be

For other awards see http://www.estlit.ee/elis/?cmd=writer\&id=55407\&grp=5

The novel was first published as a translation in Estonian and then in Russian in the collection Харбинские мотыльки (Belobrovtseva, Meimre 2015: 16).

4 It was published as a translation in Estonian; it has not been published in Russian. 
seen like some powerful natural phenomenon, the fifth season of the Estonian literary landscape (Larm 2016).

Attempts have been made in many interviews to treat Ivanov as a socalled model Estonian Russian and political questions have been asked but Ivanov has always distanced himself from politics, stating that he is a writer not a politician (see e.g. Afanasjev 2012). ${ }^{5}$ As many other Estonian Russianlanguage writers, Ivanov does not deal specifically with the issues of Estonian Russians in his prose, which is one of the reasons of his popularity and one of the reasons why Estonian Russian literature has caught so much attention. Ivanov depicts tendencies in the $21^{\text {st }}$ century society and deals with existential questions (see Kõvamees 2014).

Usually Ivanov's books are followed by a number of interviews and articles, which are published in the literary magazines and in various newspapers. The type of the publication defines the approach: more thorough and analytical articles can be found in the literary magazines. In the following, I am going to concentrate on the analysis of the reception of Ivanov's prose published in Estonian. The articles published in the Estonian-language and concentrating on his prose (both in newspapers and in the literary magazines) are under observation. What topics have been discussed? Which aspects of Ivanov's prose have caught the attention of the critics? ${ }^{6}$

\section{The question of belonging}

One of the topics concerning Ivanov is the question of belonging and the definition of Estonian literature. For example, in one article a question is asked: should Estonian literature be only in the Estonian-language? Various solutions have been offered concerning Ivanov: an Estonian Russian writer, a Russianlanguage Estonian writer (Afanasjev 2013). Ilona Martson, who has translated several of Ivanov's books into Estonian, has drawn attention to the fact that in the Estonian-language an author living in Estonia but writing in Russian is called 'eestivene autor' (Estonian Russian author) but in Russian it is vice versa Russian-Estonian author. This may mark the difference how readers in various

5 The issue of Ivanov's citizenship was raised at the end of 2014 and the beginning of 2015 when it was discussed whether Ivanov should be given Estonian citizenship for achievements of special merit (see e.g. Hõbemägi 2014, Larm 2015). Ivanov has commented on the issue in an interview (see Trunin 2016a).

6 One of the main researchers of the Estonian Russian-language literature Igor Kotjuh has studied the reception of Ivanov's prose (Kotjuh 2013). The Estonian researcher Jaan Ross has also briefly studied the reception of Ivanov's prose (Ross 2010). 
languages see the writer. For the Estonian reader it is important that the author is a so-called domesticated Russian. S/he searches for a different angle in the text, an original way to see Estonia, but for the Russian reader it is the other way around, as the supplement 'Estonian' has a secondary meaning (Martson 2010). Parallels with the Finnish author with Estonian roots Sofi Oksanen (born in 1977) have been drawn, stating that the literary work is important, not the nationality of the author (Juurik 2014). Tarmo Jüristo also finds the question of belonging to a certain national literary tradition to be of secondary importance. For example, in the case of Franz Kafka (1883-1924) it is not discussed whether his works belong to the Czechs (whose country he lived in), to the Germans (whose language he wrote in) or to the Jews (as he was of Jewish origin) (Jüristo 2015). Heili Sibrits has also stated, concerning the novel Peotäis porrmu, that the book is about the people living in the Estonian Republic, the nationality has absolutely no importance here (Sibrits 2012).

It has also been noted that there are different ways to define identity: state nationalism (common in the West) and ethnic nationalism (common in the East) (Kotjuh 2010: 139). Especially small nations like Estonians tend to define one's identity according to the language spoken and ethnicity, not the citizenship. Therefore, someone whose native language is Russian is considered to be Russian, although s/he may have the Estonian citizenship.

Accordingly, Ivanov tends to be perceived as someone with the knowledge of the Russians living in Estonia. He gives an insight into the world of Estonian Russians. The autobiographical aspect is brought forward and parallels between the author and his characters are drawn, especially in the works dealing with contemporary themes (e.g. Minu Taani onuke, Tuhk, Peotäis pormu), although Ivanov has repeatedly stated that he is not his literary characters (Belobrovtseva, Meimre 2015: 22). ${ }^{7}$ For example,

Ivanov's short stories and novels are deeply personal, both in form and content. As for identity, their first-person narrators have also "fallen between two chairs": a Russian man without citizenship, born in Tallinn, who left Estonia in the 1990s and spent years in Scandinavia, unable to settle anywhere. As a result, Ivanov's work is pure littérature mineure, where the individual theme becomes enlarged under the microscope [...]. Through this other story, the reader sees a world that did not exist before, together with people who up to now were invisible, and in the centre the first-person hero

Ivanov has said that it was never his intention to write his life story but to construct texts that originate from his experiences. He has said that he does not find himself interesting but the stories that he is telling have to be interesting. Therefore, the reader should be interested in the characters, not in him (Ross 2011: 93-94). 
Found in Translation

of Baltic-Russian extraction, "whose collar is buttoned up and whose heart is flowing over with contempt" (Jüristo 2014). ${ }^{8}$

Andres Kurg has also stated in his thorough article concerning Minu Taani onuke and Tuhk that Ivanov's prose is to a great extent based on autobiographical material (Kurg 2010). However, parallels are drawn not only with contemporary but also with earlier works, for example in the case of the novel Harbini öoliblikad which is set in the 1920s and 1930s:

The main character, a young artist Boriss Rebrov, is [...] an aspect of Ivanov. There are many parallels between Rebrov and Ivanov, at times thing are even heading towards self-irony. [...] Rebrov's world-view largely coincides with Andrei Ivanov's view on the world. It is the same character as in the novels Hanumani teekond Lollandile and Peotäis porrmu, although these are set decades apart. It is the same intelligence, a cool attitude towards nationalism, apoliticism, knowledge of languages and via it connection with the European culture that infuses both. (Laasik 2013b) ${ }^{9}$

The ironic tendency has been noticed to be especially apparent when depicting his compatriots (see e.g. Oja 2012; Kõvamees 2014: 197). Toomas Vint has also discussed self-irony in Ivanov's works (Vint 2010).

\section{Intertextuality}

While discussing Ivanov's prose, very many different authors and texts are mentioned. Predominantly connections with Russian literature are made. It is also worth mentioning here that in several interviews Ivanov has mentioned the role of Russian literature, e.g.

My roots [...] are in Russian literature because Russia[n literature ${ }^{10}$ is my symbolic homeland. I am conditionally debating with very many writers whom I love, like Nabokov, Boris Poplavski, Dostoyevsky, Fjodor Sologub, I quarrel with

8 The article by Tarmo Jüristo has been published both in Estonian and in English, in this article, the latter is used.

9 All translations (except for Jüristo 2014) are mine - A.K.

10 There was a translation error, which was later corrected: the line "[...] because Russian literature is my symbolic homeland" was translated as "[...] because Russia is my symbolic homeland" (see Kulli 2014a and 2014b). This significant translation error was later brought forward in connection with the question of Ivanov's citizenship (Larm 2015). 
KÕVAMEES

Tolstoy, blame Gogol for torturing himself with the questions of Orthodoxy; and with Lermontov for going to that pointless duel... (Kulli 2014a).

Fyodor Dostoevsky (1821-1881) is one of the authors most commonly discussed in connection with Ivanov's prose. For example:

"Suffering - this is the only reason for consciousness," says Dostoyevsky in his novel Notes from the Underground, a shadow of which runs through Ivanov's entire oeuvre. The protagonist of A Journey of Hanuman and A Handful of Dust even suffers physically. [...] However, suffering also has a deeper, a Dostoyevskian dimension in Ivanov's books. It is not just a symptom or a reaction to the external environment: it is the [...] essential disharmony and alienation, which cannot be cured or eased. Nor can it be escaped or resisted, as this resistance itself would be a farce. This is something that has been woven into the texture of Ivanov's world and which constitutes the conceptual starting point of his texts. (Jüristo 2014)

The main character in Peotäis põrmu is compared with Prince Myshkin in Dostoevsky's Idiot (1868) (Kaus 2013). Dostoyevskian suffering is also mentioned in connection with the novel Bizarre (Mihkelev 2015, Aru 2015a).

Besides Dostoevsky, other Russian classics are mentioned. For example, the character of the novel A Hero of Our Time (1840) by Mikhail Lermontov (1814-1841) has been used by Tarmo Jüristo in his article The Antihero of Our Time (Jüristo 2014) and by Anneli Mihkelev (Mihkelev 2015) in her article Antikangelase porandaalused seiklused (The Adventures of the Antihero from the Underground), which at the same time refers to Dostoevsky. Ivanov has been seen as part of the more ironic and even bilious current of Russian literature beginning with Nikolai Gogol (1809-1852) and Mikhail Bulgakov (1891-1940) (Kaus 2013). In addition to the classics, more contemporary Russian writers are mentioned, e.g. in association with Ivanov's detailed style, Sergei Dovlatov (19411990) and Vladimir Sorokin (born in 1955) are mentioned (Afanasjev 2010).

Several of Ivanov's titles refer to various texts, an aspect which has been discussed by the critics, for example Peotäis porrmu (A Handful of Dust) refers to T. S. Eliot (1888-1965) and also has a moto from Eliot's The Waste Land (1922) (aspect discussed by Arno Oja (Oja 2012)). The title Hanumani teekond Lollandile $e^{11}$

11 In Estonian, the title has an additional meaning as the word 'Lolland' refers to the land of fools because in the Estonian-language 'loll' means 'fool, stupid'. This aspect has been discussed by Priit Hõbemägi (Hõbemägi 2015). 
clearly refers to Ramayana, an epic tale of a prince forced into exile and his years-long journey with his faithful companion, the monkey king. In Hindu mythology, Rāma is an "ideal person", an avatar of the god Vishnu, who has adopted the shape of a mortal in order to demonstrate dharma, the right and virtuous life. The same question is faced daily by the heroes of all of Ivanov's books: how to remain human in the world out of joint, which is anything but humane - a world that denies his humanity. (Jüristo 2014)

Parallels with Ilya Ehrenburg's (1891-1967) famous Julio Jurenito (1922) have been made in connection with Hanuman: "Ivanov's novel can be seen as a postmodern copy of Ehrenburg's Jurenito, a new version set in presentday Europe. Dark-skinned and intelligent Hanuman takes the role of Julio Jurenito, a catalyst of human souls" (Laasik 2013a). Ilona Martson has made comparisons with Don Quixote and also seen the novel as a reincarnation of Jack Kerouac's (1922-1969) On the Road (1957) as "both have a constantly moving restless friend whose meaning of life, and also the contents of the book, is formed by being on the road" (Martson 2012). There is a whole array of other authors who have been mentioned in association with Ivanov's prose, e.g. Jean-Paul Sartre (1905-1980), Albert Camus (1913-1950) (Jüristo 2014); his descriptions in Peotäis põrmu have been seen as realistic as in Émile Zola's (1840-1902) Germinal (1885) (Hõbemägi 2012). In association with the Scandinavian trilogy (Hanumani teekond Lollandile, Bizarre and Kuutõbise pihtimus) Henry Miller's (1891-1980) Tropic of Cancer (1934) and LouisFerdinand Céline's (1894-1961) Journey to the End of the Night (1932) have been mentioned (Velmet 2015: 81). ${ }^{12}$

Estonian literature is also mentioned in association with Ivanov's prose. For example, in connection with the fact that Peotäis porrmu was written in Russian but first published in Estonian, Hans Leberecht (1910-1960) is mentioned (Oja 2012). He was an Estonian writer with a German name who wrote his books in Russian, which were translated into Estonian. He is most famous for his novella Valgus Koordis (Light in Koordi, published in 1948 in Russian and 1949 in Estonian) depicting the establishment of collective farms in Estonia in the 1940s. The book is considered to be one the finest and purest examples of socialist realism in Estonian literature.

Andrei Hvostov has compared the depiction of Estonia in the 1920s and 1930s in Ivanov's Harbini öoliblikad and Paigallend (1998, published in English in 2003 as Treading Air) and Wikmani poisid (The Wikman Boys) (1988) by one

12 See also Belobrovtseva, Meimre 2015: 26 where intertextuality in Ivanov's prose published in Russian is studied. 
of the best-known Estonian writers Jaan Kross (1920-2007). The Estonian Republic where Ivanov's Russian emigrants live is "light-years away from the bright Estonian Republic in Paigallend and Wikmani poisid. Ivanov's characters are in a different place. In the backyard, if we were to look for a known symbol from Estonian literature" (Hvostov 2014: 154). Tagahoovis (In the Backyard) (1933) is a novella by the Estonian writer Oskar Luts (1887-1953), depicting among others a variety of Russian characters. Ilona Martson also mentions Luts in her review of the novel (Martson 2013). The great Estonian writer Anton Hansen Tammsaare's (1878-1940) opus magnum Tõde ja õigus (Truth and Justice) (1926-1933) is mentioned in connection with Harbini öoliblikad: "it is like someone has added an important plotline to Tammsaare's novel after which the literary republic of Estonia is not the same" (Jüristo 2015). Therefore, the era depicted in Harbini öoliblikad has generated many comparisons with various books in Estonian literature.

Parallels with Hingede öö (All Souls Night) (1953) by Estonian exile writer Karl Ristikivi (1912-1977) have been found (Kõvamees 2014: 1999; Belobrovtseva, Meimre 2015: 18). Estonian contemporary literature is represented by Mari Saat's (born in 1947) Lasnamäe lunastaja (The Saviour of Lasnamäe) (2008), a novel depicting the life of Russians in nowadays Estonia. Saat was the first who brought Estonian Russians and their problems into Estonian contemporary literature (Oja 2012). The novel won the Estonian Cultural Endowment literary prize in 2008 and is considered one of the finest examples of the (Estonian) Russian topic in Estonian literature. Another Estonian contemporary writer - Jan Kaus (born in 1971) - is mentioned in connection with Ivanov's Minu Taani onuke and Tuhk: Kaus's novel Hetk (Moment) (2009) and Ivanov's books share the same location - Kalamaja ${ }^{13}$ (Kaldmaa 2010: 12).

While the majority of the authors discussed in the articles are prose writers, nevertheless, one Estonian poet - Heiti Talvik (1904-1947) - is mentioned. One critic states that although apparently Ivanov is not familiar with Talvik, he describes similar states of mind that apprehended Talvik (Martson 2013).

\section{Alienation. Mapping the era and the society}

One of the central themes in Ivanov's prose is alienation and being an alien, a topic that is discussed in various articles, for example:

13 Kalamaja, 'Fish House' in Estonian, is a district in Northern Tallinn. 
[i] $\mathrm{t}$ is the [...] essential disharmony and alienation, which cannot be cured or eased. Nor can it be escaped or resisted, as this resistance itself would be a farce. This is something that has been woven into the texture of Ivanov's world and which constitutes the conceptual starting point of his texts. [...] They [his characters] desperately try to find any kind of foothold, which however keeps slipping away from them. Their best intentions come to nothing, their aspirations turn out to be pointless, and they are stuck in the same place, without getting anywhere. The ensuing hopelessness is not ennobling, and does not lead to the intellectual emancipation and the sense of absurd of novels by Sartre or Camus: this is Bardamu's anxiety in Céline's novel Journey to the End of the Night. (Jüristo 2014) $)^{14}$

His characters have been named using the term 'a man between' (Belobrovtseva, Meimre 2015: 18) and an existential outsider (Kõvamees 2014) who finds it impossible to run from oneself and one's burden (Afanasjev 2010). He depicts people who belong to the cultural periphery (Mihkelev 2015). His characters have also been described as "people who want to belong somewhere. No one believes in nothing, not the state nor the society in general, not even one's own family. And everyone is occupied by the self-deception" (Aru 2015a). Ivanov's characters tend to fail in their attempts to give meaning to the surrounding bustling and finding their place (Aru 2015b).

However, alienation is not only adaptable to his characters but also to the whole society and places. As it is marked about the changes in the 1990s, after the collapse of the Soviet Union: not only did the value system and institutions collapse but also the place to identify oneself with turned alien (Kurg 2010) and the Russians living in Estonia found themselves in a totally new situation (Kõvamees 2015: 86-87). Ivanov is interested primarily in the modern times, how people live here and now. For example, Estonia as depicted by Ivanov in his Peotäis porrmu is somehow cold; people are alienated and turned into machines: one has to produce pointless objects and another has to sell these and yet another one has to create bureaucratic rules for both of them. It is the life and land where there is nothing grand, there is no hope and miracles do not happen. Nobody is truly free (Tigasson 2012). Alienation is not only adaptable to Estonia but to the society in a broader sense; the Scandinavian trilogy is a good example of this.

14 See also Kõvamees 2015: 86-88. 


\title{
Conclusion
}

Andrei Ivanov has become the most prominent Estonian Russian-language writer whose prose is very popular among Estonian readers: his books are bestsellers and widely discussed in newspapers, blogs and in the literary magazines. Based on the analysis of the articles published in Estonian and concentrating on his prose (both in newspapers and in the literary magazines), it may be concluded that the most discussed books are Hanumani teekond Lollandile, Peotäis põrmu, Harbini ööliblikad and Minu Taani onuke/Tuhk. The most often discussed topics are alienation, the question of belonging and intertextuality.

It can be said in conclusion that the position of Estonian Russian literature has shifted from the periphery into the spotlight and the works by Ivanov have played an important role in that process. The author has entered the Estonian cultural field through translations, it may be said that he has been found in translations. It is evident from the reception that he has opened new perspectives and induced discussions, for example about the definition of Estonian literature and the position of Estonian Russians and the Estonian Russian-language literature. However, it is also clear that he is not specifically only Estonian-Russian oriented, frequently "the Estonian-Russian background proves to be a helpful tool for creating characters who are alienated, thus giving a piercing look into the modern society" (Kõvamees 2015: 91). Ivanov is generally considered a writer who speaks to modern readers and offers a novel perspective on society.

\author{
Anneli Kõvamees \\ anneli.kovamees@tlu.ee \\ Tallinna Ülikool \\ Humanitaarteaduste instituut \\ Narva mnt 29 \\ 10120 Tallinn \\ EESTI / ESTONIA
}

\section{References}

Afanasjev, V. 2010. Impeeriumi vaeslapse kannatused. - Looming, 6, http://www. looming.ee/index2.php?archive_mode=article\&articleid=392 (04.07.2015).

Afanasjev, V. 2012. Rahvusvahelise kirjanduse kodanik Andrei Ivanov. - Eesti Ekspress, 01.12. http://www.ekspress.ee/archive/print.php?id=65333836 (08.01. 2014). 
Found in Translation

Afanasjev, V. 2013. Heal kirjandusel mitu keelt. - Eesti Ekspress, 11.02. http:// ekspress.delfi.ee/news/arvamus/vahur-afanasjev-heal-kirjandusel-mitukeelt?id=65638984 (04.07.2015).

Aru, E. 2015a. Enesepetjad liiguvad heaoluühiskonna äärealadel. - Eesti Päevaleht, 19.01 .

Aru, E. 2015b. Jämejala, Patarei ja happy end. - Eesti Päevaleht, 30.03.

Belobrovtseva, I., Meimre, A. 2015. Kirjutamine kui püsikestev peeglistaadium. Keel ja Kirjandus, 1, 16-32.

Hvostov, A. 2014. Emigrandi käsiraamat, oikumeeniline. - Vikerkaar, 4-5, 153-156.

Hõbemägi, P. 2012. Leia hirm ja lahendad mõisatuse. - Eesti Ekspress, 27.03. http://ekspress.delfi.ee/news/areen/nadala-raamat-leia-hirm-ja-lahendadmoistatuse?id=64127061 (04.07.2015).

Hõbemägi, P. 2014. (Ne)nužnõi tšelovek. - Eesti Ekspress, 31.12.

Hõbemägi, P. 2015. Hinge laboratoorium. - Eesti Ekspress, 11.03.

Juurik, M. 2014. http://www.tuglas.fi/index.php?id=2052 (04.07.2015).

Jüristo, T. 2014. Andrei Ivanov and the Anti-hero of Our Time. - ELM (Estonian Literary Magazine), 1, http://www.estlit.ee/elis/?cmd=writer\&id=55407\& $\mathrm{txt}=7061(22.10 .2014)$.

Jüristo, T. 2015. Suurem kui vaid eesti kirjandus. - Eesti Ekspress, 11.03.

Kaldmaa, K. 2010. Lapsepõlv Kalamajas. - Lugu, 3, 12.

Kaus, J. 2013. Külmas tegelikkuses. - Postimees, 02.02. http://kultuur.postimees. ee/1123780/kulmas-tegelikkuses (04.07.2015).

Kotjuh, I. 2010. Eesti venekeelne kirjandus: kas osa eesti või vene kirjandusest? - Keel ja Kirjandus, 2, 134-139.

Kotjuh, I. 2013. Eesti venekeelse kirjanduse nullindate põlvkond: vastuvõtt ja tõrked omaks tunnistamisel. - Methis, 11, 64-83.

Kulli, J. 2014a. Eestis sündinud kirjanik Andrei Ivanov: "Minu sümboolne kodumaa on ikkagi Venemaa”. - Õhtuleht, 22.03. http://www.ohtuleht.ee/569080/eestissundinud-kirjanik-andrei-ivanov-minu-sumboolne-kodumaa-on-ikkagi-venemaa(04.07.2015).

Kulli, J. 2014b. Täpsustus. - Õhtuleht, 29.03. http://www.ohtuleht.ee/573958/ tapsustus (4.07.2015).

Kurg, A. 2010. Viimane nõukogude põlvkond eksiilis. - Vikerkaar, 7-8, http:// www.vikerkaar.ee/index1.php?page $=$ Arhiiv\&a_act $=$ article\&a_number $=5136$ (22.10.2014).

Kõvamees, A. 2014. "A Handful of Dust": the Case of Estonian Russians and Existential Outsiderness. - Interlitteraria, 19(1), 193-201. DOI: http://d x.doi. org/10.12697/IL.2014.19.1.14

Kõvamees, A. 2015. Out of the Unknown and into the Limelight: The Case of Estonian Russian Literature. - Interlitteraria, 20(1), 83-93. DOI: http://dx.doi. org/10.12697/IL.2015.20.1.7

Laasik, A. 2013a. Immigrandi hüppelaud Taani Ibizale. - Eesti Päevaleht, 14.01. http://epl.delfi.ee/news/kultuur/immigrandi-huppelaud-taani-ibizale?id= 65523938 (04.07.2015). 
KÕVAMEES

Laasik, A. 2013b. Ivanovi uus teos: Vene kunstnik jalutab läbi Eesti Vabariigi. Eesti Päevaleht, 21.10. http://epl.delfi.ee/news/kultuur/ivanovi-uus-teos-venekunstnik-jalutab-labi-eesti-vabariigi?id=66943416 (4.07.2015).

Larm, P.-R. 2015. Hämal on lühikesed jalad. - Sirp, 06.02. http://www.sirp.ee/s1artiklid/c9-sotsiaalia/hamal-on-luhikesed-jalad/ (04.07.2015).

Larm, P.-R. 2016. Natuke kära - ei millestki? - Sirp, 04.03.

Martson, I. 2010. Kolm eestivene kirjanikku. - Epifanio, 13, http://www.epifanio.eu/ nr13/est/eestivene.html_(4.07.2015).

Martson, I. 2012. Kahe hullu uskumatud seiklused Taanimaal. - Raamat (Eesti Kirjastuste Liidu ajaleht), 22.11.

Martson, I. 2013. Ööliblikad ajaloo tõmbetuules. - Raamat (Eesti Kirjastuste Liidu ajaleht), 21.11.http://issuu.com/estbook/docs/raamat_november_2013_web/3 (04.07.2015).

Mihkelev, A. 2015. Antikangelase põrandaalused seiklused. - Sirp, 06.02. http:// www.sirp.ee/s1-artiklid/c7-kirjandus/antikangelase-porandaalused-seiklused/ (04.07.2015).

Oja, A. 2012. Elu võimalikkusest ahermaal. - Sirp, 03.02. http://www.sirp.ee/index. php?option $=$ com_content\&view $=$ article\&id $=13982$ :elu-voimalikkusest-ahermaa $1 \&$ catid=7:kirjandus\&Itemid=9\&issue $=3379$ (08.01.2014).

Ross, J. 2010. Kas Andrei Ivanov on eesti kirjanik? - Vikerkaar, 10-11, 134-136.

Ross, J. 2011. Üks jope, ühed teksad. Intervjuu Jaan Rossile. - Vikerkaar, 9, 93-99.

Sibrits, H. 2012. Valu ja vihkamine. - Postimees, 24.03.

Tigasson, K.-R. 2012. Maa, kus iial imesid ei sünni. - Eesti Päevaleht, 04.02 http:// www.epl.ee/news/kultuur/maa-kus-iial-imesid-ei-sunni.d?id=63872464 (08.01.2014).

Trunin, M. 2016a. Maailm vs. Don Quijote. - Sirp, 19.02.

Trunin, M. 2016b. Täiuslik torm amatööride maal. - Sirp, 19.02.

Velmet, A. 2015. Jevgeni Sidorovi tundekasvatus ja heaoluriigi afektiökonoomia. Vikerkaar, 6, 80-88.

Vint, T. 2010. Andrei Ivanov “Minu Taani onuke”. - Eesti Ekspress, 08.04. 